\title{
Microbiological and physicochemical evaluations of juice extracted from different parts of sugar cane stalks from three varieties cultivated under organic management
}

\author{
Avaliações microbiológicas e físico-químicas do caldo extraído de diferentes partes \\ do colmo de cana-de-açúcar de três variedades cultivadas sob manejo orgânico
}

\author{
Cristina MARTINI ${ }^{1}$, Luiz Antonio Correia MARGARIDO ${ }^{1}$, Sandra Regina CECCATO-ANTONINI ${ }^{1 *}$
}

\begin{abstract}
The artisanal production of cachaça, a beverage obtained by the fermentation of sugar cane juice after distillation, especially by small-sized producers, has traditionally used natural ferment ("fermento caipira") which consists of sugar cane juice with crushed corn, powdered rice, or citrus fruits. In despite of the difficulties in quality control due to the high level of contaminants and longer periods of preparation, the sensorial quality of the beverage may be attributed to the physiological activities of wild yeasts and even bacteria present during fermentation when this ferment is used. In this context, the aim here was to evaluate the microbiological (yeasts) and physicochemical characteristics of sugar cane juice extracted from different parts of three different varieties (RB72454, RB835486, and RB867515) of the cane stalk (lower, medium, and upper sections) in three harvesting periods (from May to December 2007) in an area under organic management. The juice from the upper section (from the eleventh internode to the top) of the sugar cane stalk could be indicated for the preparation of the natural ferment since it is as a source of yeasts and reducing sugars, especially the variety RB867515. Due to the seasonality, the best period for using this part of the sugar cane stalk is at the beginning of harvesting when the phenolic compounds are at low concentration, but there are higher number of Saccharomyces population and other yeast species. The high acidity in this section of the plant could result in a better control of bacterial contamination. These findings explain the traditional instructions of adding the upper sections for the preparation of natural ferment and can help its management in order to get a better performance with respect to organic cachaça production.

Keywords: sugar cane juice; yeasts; fermentation; organic management.
\end{abstract}

\section{Resumo}

A produção artesanal de cachaça, uma bebida obtida por fermentação do caldo de cana-de-açúcar após destilação, especialmente por pequenos produtores, tradicionalmente utiliza o fermento caipira, o qual consiste de caldo de cana misturado com milho moído, farelo de arroz e sucos de frutas cítricas. Apesar dos inconvenientes como dificuldades no controle de qualidade devido ao alto nível de contaminantes e longos períodos de preparação, a qualidade sensorial da bebida pode ser atribuída às atividades fisiológicas de leveduras selvagens e mesmo bactérias presentes durante a fermentação, quando este tipo de fermento é utilizado. Neste contexto, o objetivo deste trabalho foi avaliar as características microbiológicas (leveduras) e físico-químicas do caldo de cana extraído de diferentes partes do colmo (base, meio e ponta) em três períodos da safra (maio a dezembro) de três variedades (RB72454, RB835486 e RB 867515) em uma área sob manejo orgânico. O caldo da ponta (do $11^{\circ}$ internó até a ponta) do colmo poderia ser indicado para a preparação do fermento caipira por ser uma fonte de leveduras e açúcares redutores, especialmente da variedade RB867515. Devido ao efeito da sazonalidade, o melhor período para utilizar esta parte do colmo da cana é no início da safra, quando os compostos fenólicos estão em baixa concentração, mas com altos números de Saccharomyces e de outras leveduras. A alta acidez encontrada nesta parte do colmo poderia resultar num controle mais efetivo dos contaminantes bacterianos. Estes resultados explicam as instruções tradicionais para adição da ponta da cana para o preparo do fermento caipira e podem ajudar no seu manejo a fim de obter um melhor desempenho, no contexto da produção da cachaça orgânica inclusive.

Palavras-chave: cana-de-açúcar; leveduras; fermentação; cana orgânica.

\section{Introduction}

The term "cachaça" is usually applied to a beverage obtained by the fermentation of sugar cane juice after distillation. The cachaça production is a complex microbial process characterized by the occurrence of different yeast species with predominance of Saccharomyces cerevisiae (MORAIS et al, 1997; PATARO et al., 2000; SCHWAN et al., 2001). Basically, this beverage is processed by two distinct forms, industrial and artisanal. In the industrial segment, the process is conducted in big and medium-sized industries, with standardization and distillation in stainless columns. On the other hand, in the artisanal segment this beverage is processed in small-sized and familiar business, on small scale basis, empiric knowledge, and its distillation is carried out in copper alembic (CONFEDERAÇÃO..., 2005).

Most of the small distilleries produce cachaça by spontaneous fermentation using a natural ferment ("fermento caipira") which is prepared by various methods including the microorganisms naturally present in the sugar cane juice, or by mixing it with crushed corn, powdered rice, or citrus fruits (GOMES et al., 2007).

1 Tecnologia Agroindustrial e Sócio-Economia Rural, Universidade Federal de São Carlos - UFSCAR, CEP 13600-970, Araras - SP, Brasil, E-mail: antonini@cca.ufscar.br 
For the preparation of the naturalferment, daily addition of sugar cane juice is made during a five to seven-day period resulting in a spontaneous fermentation by wild microorganisms present in the sugar cane juice, equipment and fermentation tanks (MALTA, 2006). During fermentation, a succession of microorganisms is observed, with predominance of S. cerevisiae but also Candida sake, Kluyveromyces marxianus. and apiculated yeasts (MORAIS et al., 1997).

The artisanal production of cachaça lacks research, mainly concerning technological aspects. Much is said about the inconvenience of using natural ferment due to the difficulties in quality control because of the high level of contaminants and longer periods of preparation. The lack of control over the microorganisms responsible for fermentation may lead to organoleptic variations in the beverage, which has induced the research on the selection of Saccharomyces cerevisiae strains as culture starters (GOMES et al., 2007).

On the other hand, species of Lactobacillus, Leuconostoc, and Propionibacterium can contribute to the "bouquet" formation in cachaça when they are not present in high numbers (SCHWAN et al., 2001). For whisky production, Geddes and Riffkin (1989) observed the same condition for Lactobacillus. In these cases, the status of the bacteria in the process is not as contaminants, but as co-agents, also responsible for the final quality of the beverage (CARVALHO NETTO, 2007). Following this idea, the usage of the natural ferment should be investigated from a scientific point of view. Since the main source of microorganisms is the sugar cane juice and according to the popular knowledge that the natural fermentation can be increased by the addition of the upper section of the cane stalk, this study aimed to the microbiological (yeasts) and physicochemical evaluations of sugar cane juice extracted from different parts of three varieties of the cane stalk in three harvesting periods (from May to December) in an area under organic management. This could help to manage the preparation of the natural ferment in order to get a better performance of organic cachaça production, especially for small-sized producers.

\section{Materials and methods}

\subsection{Sampling}

The sugar cane juice was sampled as following: samples of 10 sugar cane stalks of three different sugar cane varieties, RB72454, RB835486 and RB867515 were collected from an area under organic management in the city of Araras - SP, which belongs to the Universidade Federal de São Carlos, Centro de Ciências Agrárias, in May, September, and December 2007. The stalks were cut into three sections at each five internodes and named as lower section (first to fifth internode from the root), medium section (sixth to tenth internode), and upper section (eleventh internode to the top). Each part was transferred to a shredding machine (for forage plants), and the resulting dough was subject to pressure in a hydraulic press $\left(250 \mathrm{~kg} \cdot \mathrm{cm}^{-2}\right)$ for around 2 minutes while collecting the juice extracted $(3 \mathrm{~L})$ in bottles which were frozen immediately. After each procedure, the equipment was washed with distilled water.

\subsection{Physicochemical analysis}

Sugar cane juice samples were evaluated for $\mathrm{pH}$ (by direct measurement in a pH-meter), titratable acidity (by titration of $25 \mathrm{~mL}$ of the sample with $\mathrm{NaOH} 0.1 \mathrm{~N}$ until pH 7.0), phenolic compounds (BUREAU..., 1991), Pol, Brix, purity, reducing sugar, total reducing sugar (FERNANDES, 2003), and protein (by the determination of nitrogen content through Kjeldahl's method following multiplication by 6.25 ).

\subsection{Microbiological analysis}

For yeast determination, $10 \mathrm{~mL}$ of each sugar cane juice sample were centrifuged at $3000 \mathrm{rpm}$ for 5 minutes; the supernatant was discarded, and the cell mass was washed and centrifuged again under the same conditions. The cells were resuspended in sterile saline solution $(\mathrm{NaCl} 0.85 \%)$, serially diluted in the same solution, and aliquots of $100 \mu \mathrm{L}$ were plated onto WLN (Wallerstein Laboratories Nutrient Agar, according to GREEN; GRAY, 1950 modified by OLIVEIRA; PAGNOCCA, 1988), a general counting medium; WLD (WLN + 50 ppm cicloheximide), and Lysine Agar (according to WALTERS; THISELTON, 1953 modified by MORRIS; EDDY, 1957); the last two are selective media. The plates were incubated at $30{ }^{\circ} \mathrm{C}$ for 3 days, and the number of yeasts in each medium was expressed as colony forming units. $\mathrm{mL}^{-1}\left(\mathrm{CFU} \cdot \mathrm{mL}^{-1}\right)$. To estimate the number of Saccharomyces yeasts $\left(\mathrm{CFU} \cdot \mathrm{mL}^{-1}\right)$ for each sugar cane variety during the harvesting period and the proportion of Saccharomyces yeasts (\%) along the cane stalk during the sampling periods, the following formula was applied: [(CFU.mL ${ }^{-1}$ in WLN medium - CFU.mL ${ }^{-1}$ in Lysine Agar medium $)]$ and [(Sum of Saccharomyces yeasts in a particular section $) \div$ (Sum of Saccharomyces yeasts from the lower, medium, and upper sections) $] \times 100$, respectively.

\subsection{Statistical analysis}

The results were analyzed using the SAS software through the analysis of variance and Tukey's test for a comparison between treatments (periods of sampling, sections of the cane stalks, culture media, and sugar cane varieties). The values of CFU.mL $\mathrm{mL}^{-1}$ for yeast in different culture media were log transformed before statistical analysis. The values of reducing sugars were subjected to a square root transformation before analysis.

\section{Results and discussion}

The statistical analysis showed significant differences among the treatments for each variable studied (sugar cane varieties, stalk section, culture media, and sampling periods) as well as in the interactions among these variables, except for the interaction "stalk section and culture medium" and "variety, stalk section, and culture medium".

In a general analysis using the Tukey's test for average comparisons, the sugar cane variety RB72454 showed the lowest yeast numbers; the culture medium WLN rendered the highest yeast numbers; May was the best sampling month for elevated yeast counts; and yeasts are concentrated at the upper section of cane stalk (from the $11^{\text {th }}$ internode to the top), as seen in Figure 1. 
The number of yeasts in the juice of the lower section of the cane stalk (until the $5^{\text {th }}$ internode) did not change significantly with the sugar cane variety, but for the medium and upper sections, the variety RB72454 presented the lowest numbers (Figure 2). The same results were observed when different culture media were used for this variety, especially for the selective media Lysine Agar and WLD. In WLN, this difference among the varieties was not so striking, non-wild yeasts (that do not assimilate lysine as sole carbon source and/or are not resistant to cycloheximide, such as Saccharomyces) are more frequent in the RB72454 variety juice (Figure 3).

In May, the differences in the yeast numbers are more evident comparing the three varieties. The highest values were found for RB867515, followed by RB835485, and RB72454, which is statistically significant among them. However, in September and December there was a great reduction in the

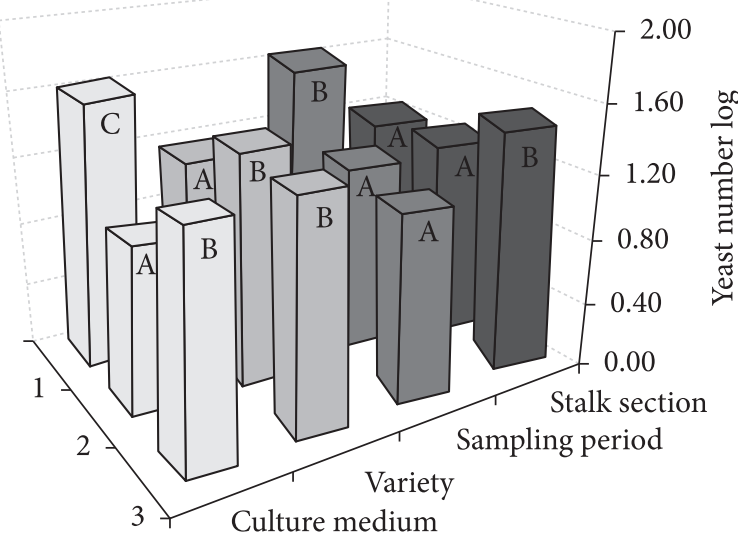

Figure 1. Log of yeast number isolated from sugar cane juice extracted from different parts of cane stalks (1-lower, 2-medium and 3-upper sections) of three varieties (1-RB72454, 2-RB835486 and 3-RB867515) cultivated under organic management in three sampling periods (1-May 2007, 2- September 2007 and 3-December 2007) using different culture media (1-WLN, 2-WLD and 3-Lysine Agar). Different letters mean significant difference at $95 \%$ of confidence level within each parameter studied.

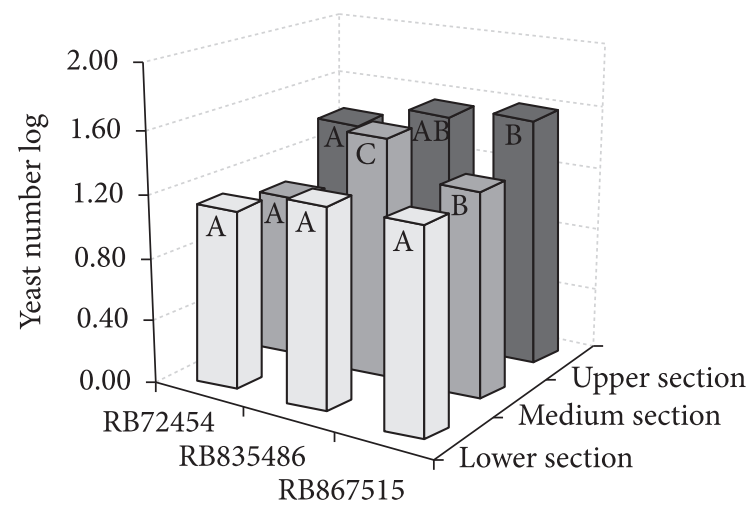

Figure 2. Log of yeast number isolated from sugar cane juice extracted from different parts of cane stalks (lower, medium and upper sections) of three varieties (RB72454, RB835486 and RB867515) cultivated under organic management. Different letters mean significant difference at $95 \%$ of confidence level among the varieties for each cane section. yeast number, in a way that striking differences are not so evident among the varieties (Figure 4). An effect of seasonality is observed.

The yeasts are concentrated in the juice from the upper section of the cane stalk (Figure 5). The yeast numbers were higher or similar in the upper section comparing to those in the medium and lower sections, which seems reasonable to indicate this part of the cane stalk for the preparation of natural ferment. According to Stupiello (2000), the utilization of the sugar cane upper sections are not indicated for sugar production because they present high content of phenolic compounds, which are precursors of the sugar colour, in addition to the fact that soluble polysaccharide and starch contents contribute to the increase of viscosity, which is undesirable for sucrose crystallization With regard to the cachaça production, Valsechi (1960) pointed out the inconvenience of using such parts basically because their

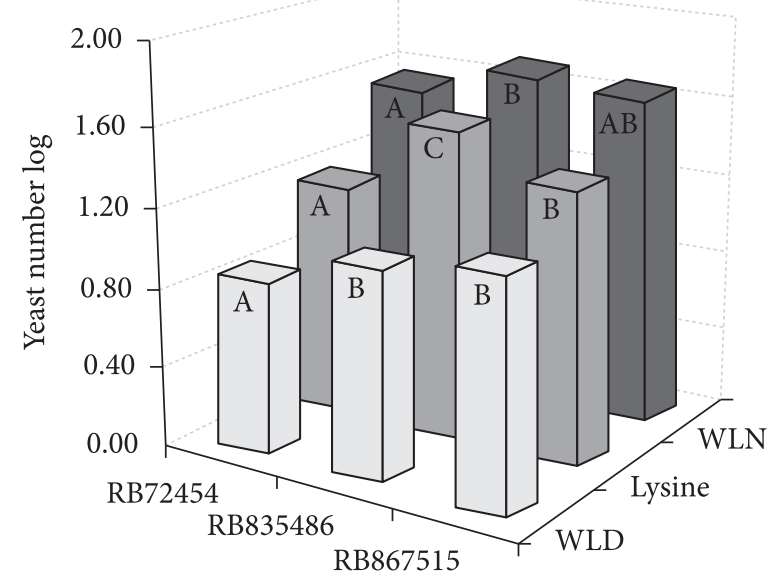

Figure 3. Log of yeast number isolated from sugar cane juice using general (WLN) and selective culture media (WLD and Lysine Agar) from three varieties (RB72454, RB835486 and RB867515) cultivated under organic management. Different letters mean significant difference at $95 \%$ of confidence level among the varieties for each culture medium.

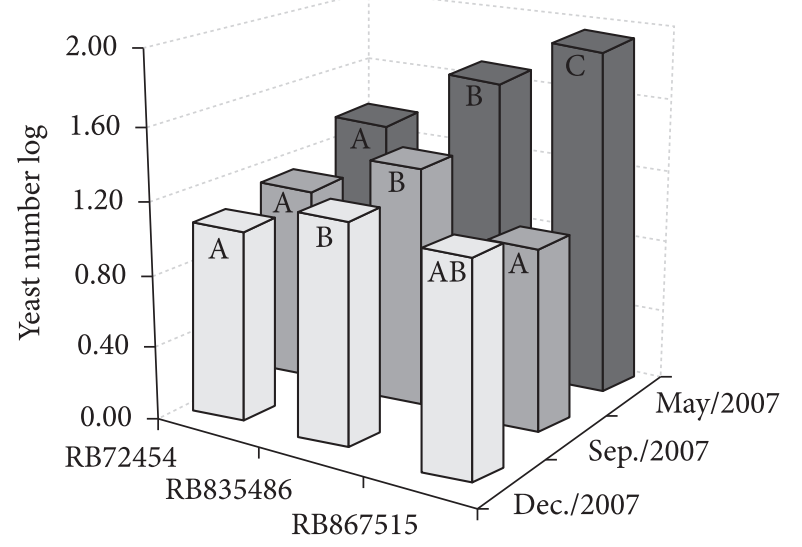

Figure 4. Log of yeast number isolated from sugar cane juice in three sampling periods (May, September and December 2007) from three varieties (RB72454, RB835486 and RB867515) cultivated under organic management. Different letters mean significant difference at $95 \%$ of confidence level among the varieties for each sampling period. 
sugar cane juice cause turbulent fermentations resulting in tank overflow. The reason for this may be the high number of yeasts and increased reducing sugar content in the upper sections of the cane stalk, as can be observed and will be discussed further on this study.

The concentration of yeasts in the juice from the upper section of the cane stalk is remarkable through the sampling periods (May, September, and December) although the number of yeasts decreased along the time (Figure 6).

In May, the yeast total counts (isolated from WLN) did not differ significantly from the natural ferment counts (isolated from WLD and Lysine Agar), suggesting that the number of Saccharomyces was not so expressive. Although this yeast genus was not individually approached, it is possible to assess its number by subtracting the number of yeasts growing on Lysine

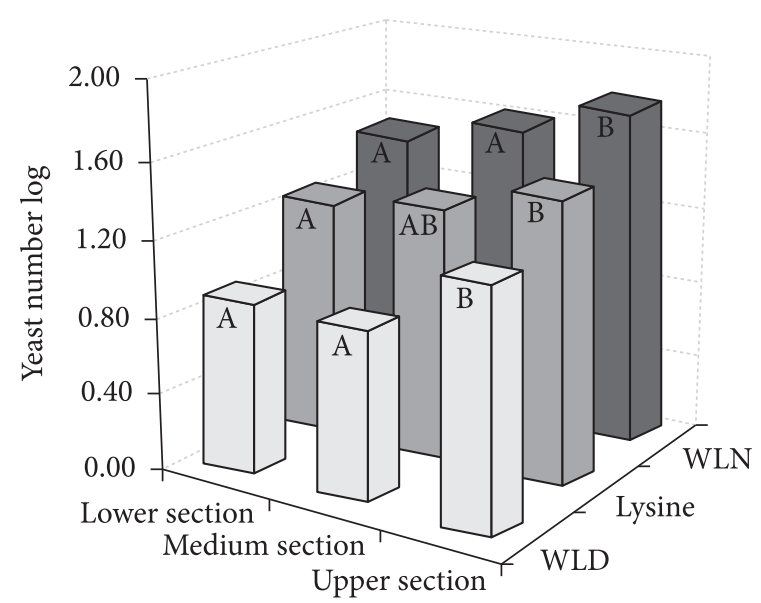

Figure 5. Log of yeast number isolated from sugar cane juice extracted from different parts of cane stalks (lower, medium and upper sections) using general (WLN) and selective culture media (WLD and Lysine Agar), cultivated under organic management. Different letters mean significant difference at $95 \%$ of confidence level among the sections of cane stalks for each culture medium.

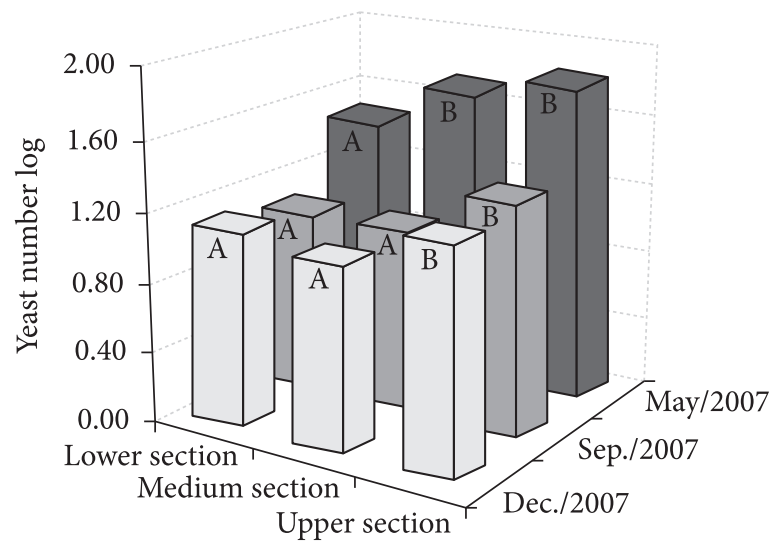

Figure 6. Log of yeast number isolated from sugar cane juice extracted from different parts of cane stalks (lower, medium and upper sections) in three sampling periods (May, September and December 2007), cultivated under organic management. Different letters mean significant difference at $95 \%$ of confidence level among the sections of cane stalks for each sampling period. agar medium (which are non-Saccharomyces, once this genus cannot assimilate lysine as sole carbon source) from the number of yeasts growing in WLN medium (non-selective medium).

The same observation is set for the results in September, but in December the yeast counts in WLN medium were significantly different from the counts in Lysine Agar (Figure 7).

Total yeast and Saccharomyces numbers found in the sugar cane juice from the three varieties along the harvest period, regardless the stalk section, are shown in Figure 8. High numbers of both yeasts were observed for RB867515 also showing the effect of seasonality on the number of Saccharomyces. Although

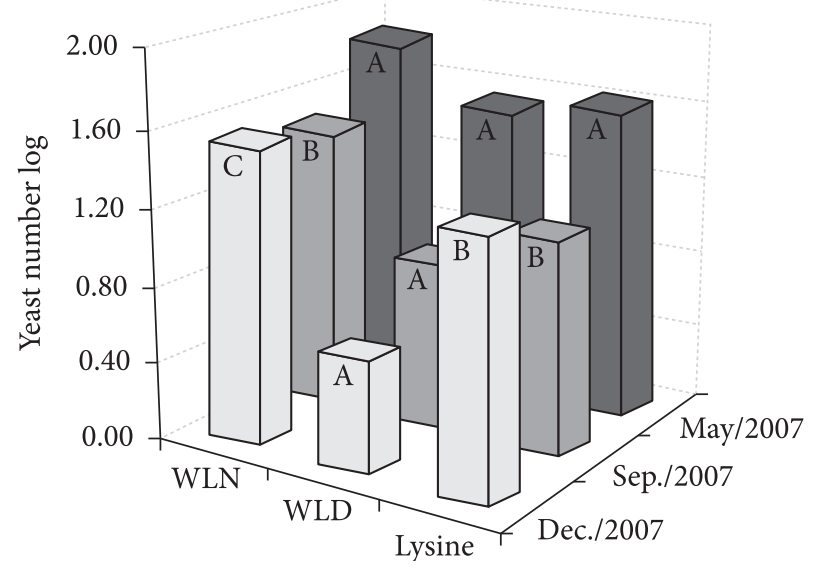

Figure 7. Log of yeast number isolated from sugar cane juice using general (WLN) and selective culture media (WLD and Lysine Agar) in three sampling periods (May, September and December 2007), cultivated under organic management. Different letters mean significant difference at $95 \%$ of confidence level among the culture media for each sampling period.

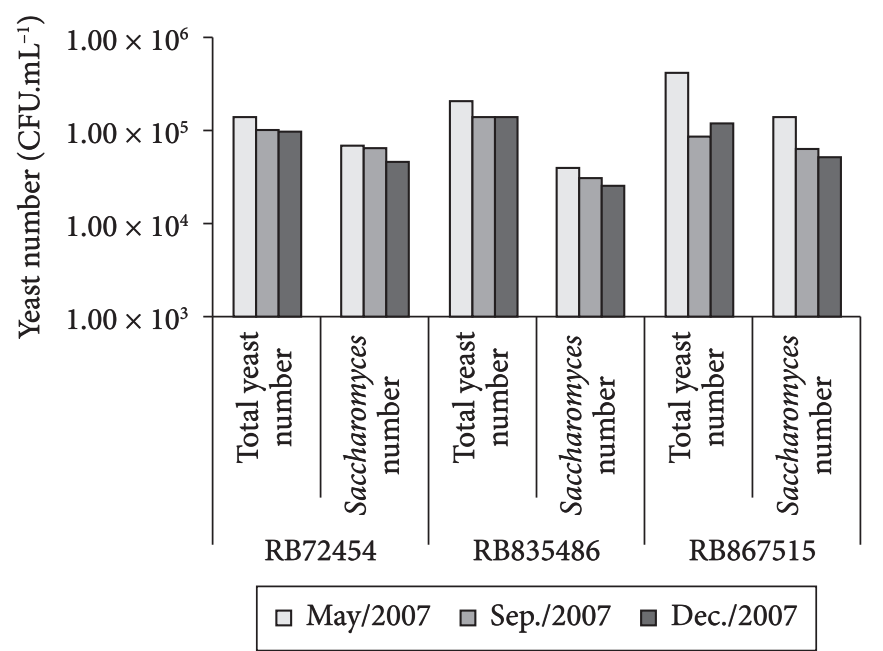

Figure 8. Total yeast and Saccharomyces numbers $\left(\mathrm{CFU} \cdot \mathrm{mL}^{-1}\right)$ found in sugar cane juice from three varieties (RB72454, RB835486 and RB867515) cultivated under organic management, in three sampling periods. Total yeast number refers to the sum of colonies in WLN medium from the three stalk sections and the number of Saccharomyces yeasts was deducted from the numbers found in WLN medium and Lysine Agar medium, as described in Material and Methods. 
the number of yeasts was always the lowest in the juice from the RB72454 variety, the proportion of Saccharomyces is considerably high, similar to the results obtained for RB867515 (Figure 9). Both are considered late and medium-late maturity varieties, respectively, in opposite to the variety RB835486, which is considered as early maturity variety (BRASIL, 2008), which may explain this substantial difference in the number of Saccharomyces. With regard to the RB835486 variety, the number of Saccharomyces was stable since May since the sugar cane had already reached its point of maturity; for the other two varieties, the number of Saccharomyces increases with sugar cane maturation, decreasing in December. Nonetheless, the number of these yeasts was always lower in the variety RB835486.

Regarding the stalk section, the late or medium-late maturity varieties (RB72454 and RB867515) presented concentration of Saccharomyces in the upper and medium sections preferably, while RB835486 showed more concentration of these yeasts in the lower and medium sections (Figure 10). There was also an

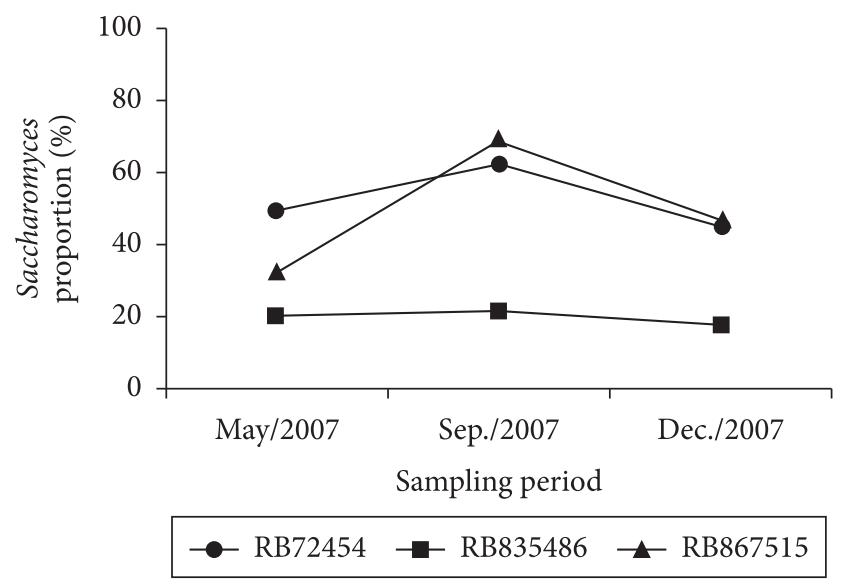

Figure 9. Saccharomyces proportion (\%) found in sugar cane juice extracted from three varieties (RB72454, RB835486 and RB867515) cultivated under organic management, in three sampling periods. The proportion of Saccharomyces yeasts was calculated in relation to the total yeast number (in WLN). effect of seasonality on the distribution of Saccharomyces along the sugar cane stalk. Generally, the number of Saccharomyces was higher in the upper section, except for the RB835486 in May and September.

The results of the physicochemical analysis of all samples of sugar cane juice are presented in Table 1. Regarding the sugar cane varieties, RB835486 showed some significant differences in the total reducing sugar and phenolic compounds in relation to the other varieties. The differences among the sections of cane stalk are evident for some parameters such as Pol, Brix, reducing sugars, $\mathrm{pH}$, and acidity. Two results could be highlighted: higher reducing sugar content and higher acidity (significant at $5 \%$ ) observed in the upper section of cane stalk compared to the other sections. This could be related to the increased number of Saccharomyces yeasts in this part of the cane stalk as showed before. It can be said that, the more the reducing sugar

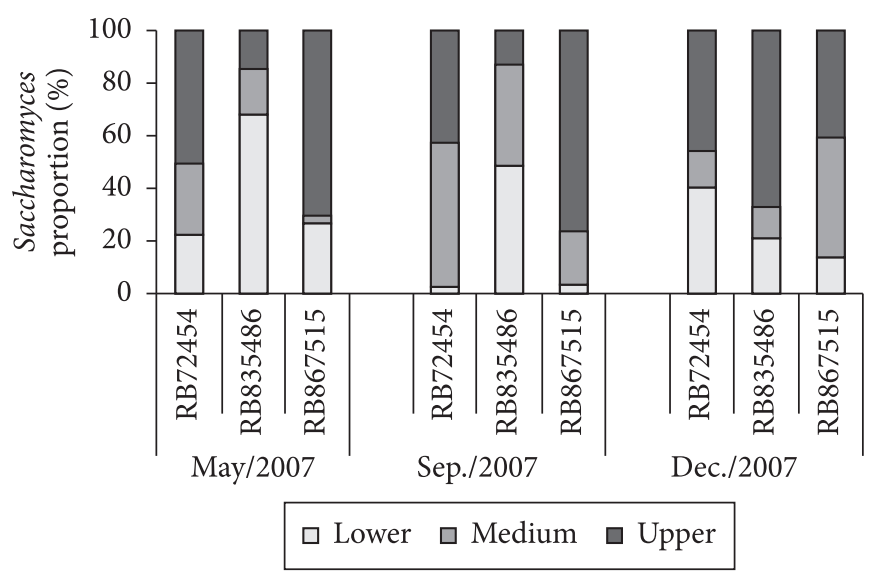

Figure 10. Saccharomyces proportion (\%) found in sugar cane juice extracted from different parts of cane stalks (upper section, medium section and lower section), from three varieties (RB72454, RB835486 and RB867515) cultivated under organic management, in three sampling periods. The number of Saccharomyces yeasts was deducted from the numbers found in WLN medium and Lysine Agar medium, as described in Material and Methods.

Table 1. Physico-chemical analysis of sugar cane juice extracted from different parts of cane stalks (upper, medium and lower sections) from three varieties (RB72454, RB835486 and RB867515) cultivated under organic management, during a harvesting period (May, September and December 2007) ${ }^{1}$.

\begin{tabular}{|c|c|c|c|c|c|c|c|c|c|}
\hline \multirow[t]{2}{*}{ Analysis } & \multicolumn{3}{|c|}{ Sugar cane variety } & \multicolumn{3}{|c|}{ Stalk section } & \multicolumn{3}{|c|}{ Sampling period } \\
\hline & RB72454 & RB835486 & RB867515 & Lower & Medium & Upper & May 2007 & Sep. 2007 & Dec. 2007 \\
\hline Pol (\%) & $17.19^{\mathrm{a}}$ & $16.50^{\mathrm{a}}$ & $17.44^{\mathrm{a}}$ & $18.08^{\mathrm{a}}$ & $18.01^{\mathrm{a}}$ & $15.05^{\mathrm{b}}$ & $11.89^{\mathrm{b}}$ & $19.77^{\mathrm{a}}$ & $19.47^{\mathrm{a}}$ \\
\hline $\operatorname{Brix}\left({ }^{\circ}\right)$ & $19.28^{\mathrm{a}}$ & $18.84^{\mathrm{a}}$ & $19.81^{\mathrm{a}}$ & $20.02^{\mathrm{a}}$ & $20.21^{\mathrm{a}}$ & $17.70^{\mathrm{b}}$ & $15.19^{\mathrm{b}}$ & $21.70^{\mathrm{a}}$ & $21.04^{\mathrm{a}}$ \\
\hline Purity (\%) & $88.60^{\mathrm{a}}$ & $85.96^{\mathrm{a}}$ & $85.87^{\mathrm{a}}$ & $89.87^{\mathrm{a}}$ & $88.61^{\mathrm{a}}$ & $81.94^{\mathrm{a}}$ & $76.58^{\mathrm{b}}$ & $91.36^{\mathrm{a}}$ & $92.48^{\mathrm{a}}$ \\
\hline $\mathrm{RS}^{*}\left(\mathrm{~g} .100 \mathrm{~mL}^{-1}\right)$ & $0.84^{\mathrm{a}}$ & $1.18^{\mathrm{a}}$ & $1.01^{\mathrm{a}}$ & $0.80^{\mathrm{b}}$ & $1.00^{\mathrm{ab}}$ & $1.26^{\mathrm{a}}$ & $2.08^{\mathrm{a}}$ & $0.53^{\mathrm{b}}$ & $0.43^{\mathrm{b}}$ \\
\hline $\mathrm{TRS}^{\star *}\left(\mathrm{~g} .100 \mathrm{~mL}^{-1}\right)$ & $19.90^{\mathrm{a}}$ & $18.88^{\mathrm{a}}$ & $21.40^{\mathrm{a}}$ & $19.78^{\mathrm{a}}$ & $21.40^{\mathrm{a}}$ & $18.99^{\mathrm{b}}$ & $12.98^{\mathrm{b}}$ & $23.81^{\mathrm{a}}$ & $23.39^{\mathrm{a}}$ \\
\hline Protein (\%) & $0.60^{\mathrm{a}}$ & $0.60^{\mathrm{a}}$ & $0.59^{\mathrm{a}}$ & $0.54^{\mathrm{a}}$ & $0.65^{\mathrm{a}}$ & $0.61^{\mathrm{a}}$ & $0.68^{\mathrm{a}}$ & $0.68^{\mathrm{a}}$ & $0.43^{\mathrm{b}}$ \\
\hline Acidity $\left(\mathrm{g} \mathrm{H}_{2} \mathrm{SO}_{4} \cdot \mathrm{L}^{-1}\right)$ & $0.21^{\mathrm{a}}$ & $0.20^{\mathrm{a}}$ & $0.25^{\mathrm{a}}$ & $0.19^{\mathrm{b}}$ & $0.17^{\mathrm{b}}$ & $0.29^{\mathrm{a}}$ & $0.33^{\mathrm{a}}$ & $0.20^{\mathrm{b}}$ & $0.12^{\mathrm{c}}$ \\
\hline $\mathrm{pH}$ & $5.59^{\mathrm{a}}$ & $5.54^{\mathrm{a}}$ & $5.55^{\mathrm{a}}$ & $5.60^{\mathrm{ab}}$ & $5.62^{\mathrm{a}}$ & $5.46^{\mathrm{b}}$ & $5.54^{\mathrm{a}}$ & $5.53^{\mathrm{a}}$ & $5.61^{\mathrm{a}}$ \\
\hline $\begin{array}{l}\text { Phenolic compounds } \\
\text { (ppm gallic acid) }\end{array}$ & $124.14^{\mathrm{ab}}$ & $114.49^{\mathrm{b}}$ & $137.00^{\mathrm{a}}$ & $131.11^{\mathrm{a}}$ & $125.21^{\mathrm{a}}$ & $119.31^{\mathrm{a}}$ & $39.95^{\mathrm{b}}$ & $169.99^{\mathrm{a}}$ & $165.69^{a}$ \\
\hline
\end{tabular}

${ }^{\star}$ Reducing sugar; ${ }^{* *}$ total reducing sugar; ${ }^{1}$ different letters in the lines mean significant differences at $95 \%$ of confidence level within each parameter studied (variety, stalk section, and period). 
content (easily available for yeasts) and the more the acidity (controlling the bacteria growth), the more the fermentation, which could explain Valsechi (1960), argument, as mentioned above. Therefore, a question is raised: why not using the upper section of the cane stalk as source of microorganisms and sugar for growth for the preparation of natural ferment at the beginning of harvest? A clear effect of seasonality is observed for all parameters in accordance with the literature concerning the increase in the sugar content and purity of cane juice.

According to Stupiello (2000), the upper section of the cane stalk showed higher reducing sugar, aminoacid, starch, organic acid, phenolic compound, and total polysaccharide contents, and low sucrose content. Starch and polysaccharide were not determined in this research, but phenolic compounds and protein were not significantly different from the other parts of the cane stalk (Table 1). This study did not evaluate these differences in relation to the soil management (organic $x$ conventional) to verify to what extent this could influence the technological and biological parameters of sugar cane.

Our aim was to evaluate different sections of the cane stalk in order to indicate the convenience of using them as source of microorganisms to prepare the natural ferment and what is behind the knowledge of using the upper section in this procedure. Chaves (2002) indicated it as nutrient for yeasts. It seems that the richness in yeasts is also dependent on the cane variety and harvest period in such a way that the upper sections of the variety RB867515 could be recommended for the preparation of natural ferment at the beginning of harvest. The convenience of using natural starter ferment should be investigated in light of the sensorial quality of cachaça, and for organic sugar cane producers, natural additives could be recommended to inhibit bacterial contaminants. Testing the effect of adding only the upper section of cane stalk, which presents elevated acidity, over the bacteria populations during the preparation of natural ferment could result in diminished level of contaminants to be carried into the fermentation tanks for cachaça production. Anyway, a lot of research is demanded in the universe of small producers for this beverage production to get quality and good market prices.

\section{Conclusions}

The juice from the upper section of sugar cane stalk could be indicated for the preparation of natural starter ferment as a source of yeasts and reducing sugars, especially for small-sized producers of cachaça. Due to seasonality, the best period for using this part of the sugar cane stalk is at the beginning of harvest (May), when phenolic compounds are in low concentration but Saccharomyces and other yeasts are in higher numbers and the acidity is high, especially using the variety RB867515.

\section{Acknowledgments}

The authors are grateful for the financial support provided by the foundations Fapesp (process $n^{\circ} 07 / 06979-8$ ) and CNPq and to Dr Norberto Antonio Lavorenti (CCA/UFSCar) and MSc Edjane Gonçalves de Freitas for their helpful assistance in statistical analysis.

\section{References}

BRASIL. Ministério da Educação. Universidade Federal de São Carlos. Programa de melhoramento genético da cana-de-açúcar. Catálogos. Disponível em: <http://pmgca.dbv.cca.ufscar.br/htm/catal/>. Acesso em: 09 out. 2008.

BUREAU OF SUGAR EXPERIMENT STATIONS - BSES. The standard laboratory manual for Australian sugar mills. Brisbane, 1991. v. 2.

CARVALHO NETTO, O. V. Identificação de bactérias contaminantes de fermento de cachaça por sequenciamento do gene $16 \mathrm{~S}$ rDNA. 2007. 51 p. Dissertação (Mestrado) - Universidade de São Paulo, Piracicaba, 2007.

CHAVES, J. B. P. Cachaça: produção artesanal de qualidade. 2. ed. Viçosa: CPT, 2002. 144 p.

FERNANDES, A. C. Cálculos na agroindústria da cana-de-açúcar. 2. ed. Piracicaba: STAB, 2003. 240 p.

GEDDES, P. A.; RIFFKIN, H. L. Influence of lactic acid bacteria on aldehyde. ester and higher alcohol formation during Scotch whisky fermentation. In: PIGGOT, J. R.; PATERSON, A. (Eds.). Distilled beverage flavours. Chichester: Ellis Horwood, 1989. p. 193-199.

GOMES, F. C. O. et al. Use of selected indigenous Saccharomyces cerevisiae strains for the production of the traditional cachaça in Brazil. Journal of Applied Microbiology, v. 103, n. 6, p. 2438-2447, 2007.

GREEN, S. R.; GRAY, P. P. A differential procedure applicable to bacteriological investigation in brewing. Wallerstein Laboratory Communications, v. 13, p. 357-366, 1950.

CONFEDERAÇÃO NACIONAL DA INDÚSTRIA. Instituto Euvaldo Lodi. O novo ciclo da cana: estudo sobre a competitividade do sistema agroindustrial da cana-de-açúcar e prospecção de novos empreendimentos. Brasília, DF: IEL/NC-Sebrae, 2005. 344 p.

MALTA, H. L. Estudos de parâmetros de propagação de fermento (Saccharomyces cerevisiae) para produção de cachaça de alambique. 2006. 70 p. Dissertação (Mestrado)-Universidade Federal de Minas Gerais, Belo Horizonte, 2006.

MORAIS, P. B. et al. Characterization and succession of yeast populations associated with spontaneous fermentations during the production of Brazilian sugar cane aguardente. World Journal of Microbiology and Biotechnology, v. 13, n. 2, p. 241-243, 1997.

MORRIS, E. O.; EDDY, A. A. Method for the measurement of wild yeast infection in pitching yeast. Journal of the Institute of Brewing, v. 63, n. 1, p. 34-35, 1957.

OLIVEIRA, M. F. L.; PAGNOCCA, F. C. Aplicabilidade de meios seletivos empregados nas indústrias cervejeiras à detecção de leveduras nas indústrias sucroalcooleiras. In: SIMPÓSIO NACIONAL DE FERMENTAÇÃO, 8., 1988, São Lourenço. São Lourenço: CNPq, 1988. p. 78-81.

PATARO, C. et al. Communities and genetic polymorphism of Saccharomyces cerevisiae strains associated with artisanal fermentation in Brazil. Journal of Applied Microbiology, v. 89, n. 1, p. 24-31, 2000.

SCHWAN, R. F. et al. Microbiology and physiology of cachaça (aguardente) fermentations. Antonie van Leeuwenhoek, v. 79, n. 1, p. 89-96, 2001.

STUPIELLO, J. P. Pontas de cana: problema industrial ? STAB: açúcar, álcool e subprodutos, v. 18, n. 4, p. 12, 2000.

VALSECHI, O. Aguardente de cana-de-açúcar. Piracicaba: Esalq, 1960. $116 \mathrm{p}$.

WALTERS, L. S.; THISELTON, M. R. Utilization of lysine by yeasts. Journal of the Institute of Brewing, v. 59, p. 401, 1953. 